\title{
THE VALUE OF AN IMMATURE PLANTATION ${ }^{1}$
}

\section{BY A. J. O'CONNOR}

$\mathrm{T}$

HE FOLLOWING is an account (quite unreliable from the viewpoint of Court procedure) of the proceedings in a purely imaginary case involving a claim for compensation for loss sustained in the destruction of a 20 acre plantation by fire caused by the carelessness of the defendant. The plantation in question consisted of eucalypts grown for mining poles, and was destroyed when it was four years old, i.e., before the trees had any sale value. (Incidentally, the basic data, i.e., the rotation, the final value, and initial outlay, may be accepted as authentic if circumstances are particularly favourable.)

The first witness called on behalf of the claimant was a young professional forester. In spite of (perhaps because of) his youth and inexperience he felt confident that the evidence he was about to give on the value of the plantation at the time of its destruction could not be seriously quesioned. He thought himself thoroughly entrenched by his text books in giving the expectation value. Cross examination would no doubt be centred on the rotation he had adopted ( 8 years) on the final value of the crop ( $\$ 4810 \mathrm{~s}$. Od. per acre) and the rate of interest ( 5 per cent.). He had, however, gone to a great deal of trouble in arming himself with solid facts in support of the rotation, the final yield of similar plantations and the trend in values of mining timber. As for the rate of interest, he saw no danger there either, because 5 per cent. was a fair compromise between the rates yielded by speculative and gilt edged investment. Full of confidence the witness stepped into the witness box and gave his estimate of the value of the plantation, at the time of its destruction, as $£ 39$ 9s. per acre. He explained at the same time how that figure was arrived at.

Lawyer for defendant: You state that your estimate is arrived at by adopting a rotation of 8 years, a final value of $£ 4810$ s. Od. per acre, and by discounting the latter figure at 5 per cent. compound interest down for a period of 4 years.

Witness: Yes, that is a recognised method of valuing immature plantations as I can prove. I can prove also that a rotation of 8 years and a final value of $£ 4810$ s. Od. per acre are valid assumptions.

Lawyer: Save yourself the trouble. I accept your assumption that the trees could have been sold for $£ 48$ 10s. Od. per acre had they survived until the eighth year. (The witness sighs with relief.) What I am leading up to, however, is this: You say, and I agree, that a sum of $£ 48.5$ discounted at 5 per cent, for 4 years amounts to $£ 399 \mathrm{~s}$. In other words you maintain that if the claimant could get an amount equal to $£ 39$ 9s. per acre for every acre destroyed he could invest it at 5 per cent. and after 4 years realise $\$ 48.5$ per acre.

Witness (after some hesitation): You can put it that way if you like.

Lawyer: But the statement just made does not in any way prove that the value of the plantation was $£ 39.9$ per acre when it was destroyed. It is

1. Reprinted from The Jouinal of the South African Forestry Association. Vol. 6, April, 1941: 49-53. 
merely the figure the claimant hopes to receive.

Witness: Nevertheless, from the calculations I have detailed, it is a fair compensation for the loss sustained by him.

Lawyer: That is for the Court to decide. Tell me, what do you think it cost the claimant to establish the plantation?

Witness (after some figuring): About $£ 3.25$ per acre.

Lawyer: I accept the estimate. Now let us go back a moment. You arrive at $£ 39.9$ per acre by discounting $£ 48.5$ down for a period of 4 years. Is there any logical reason, supposing the plantation had been destroyed when it was three instead of four years old, why the sum of $£ 48.5$ per acre should not be discounted down for a period of 5 years?

Witness (doubtfully): None as far as I can see.

Lawyer: Then there can be no logical reason against discounting the final value for a period of 6,7 or 8 years as circumstances may demand. In other words we can arrive at the value of the plantation at any stage in its development, as is shown by the line $\mathrm{AB}$ on the diagram I have here. This line indicates that, according to your calculations the value of the plantation at 0 years was $£ 32.83$ per acre. You, therefore, maintain that if the plantation had been destroyed by some act of my client immediately after it was planted, he could be fairly mulcted in the sum of $\$ 32.83$ per acre when the claimant's outlay was only $£ 3.25$ per acre.

Witness (now getting flurried): Well you see in the case of very young plantations, the loss would be assessed on the cost value, i.e., the cost of establishment plus compound interest for the time that elapsed after the initial outlay.

Lawyer: I see. In assessing the damage on cost value, I presume you would also allow 5 per cent., and would apply this method if the plantation was quite young, say one or two years old.

Witness: Yes.

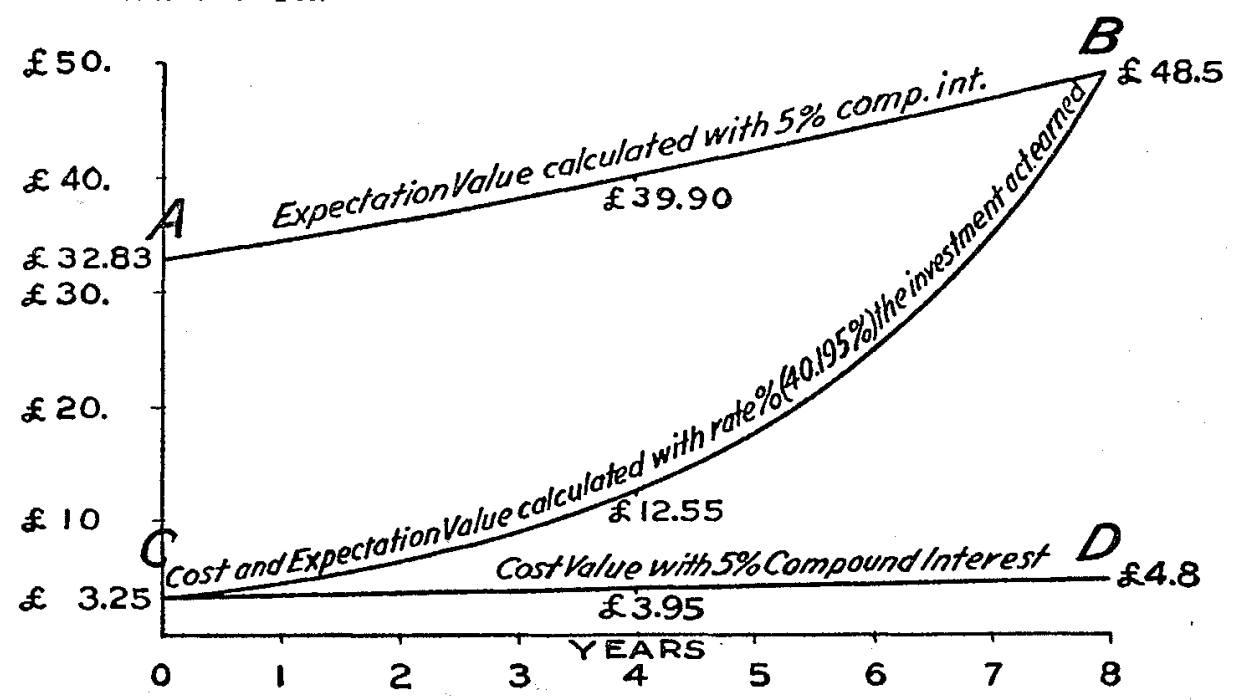


Lawyer: Then there cannot be any logical reason why the same calculation should not be applied to a plantation 3 and even 4 years old. Now $£ 3.25$ with compound interest at 5 per cent. amounts in 4 years to no more than $\$ 3.95$ per acre. How can you maintain, as you do, that my client should pay compensation at the rate of $£ 39.9$ per acre?

Witness (now quite unhappy): Well you see it depends on the way you look at the matter.

Lawyer: You mean the way you look at it. I am sorry, but I must protect my client against claims based on arbitrary viewpoints. Thank you. (A puzzled and'crest-fallen forester steps down from the witness box.) Your Worship, I submit the assessment of the damage amounting to $\$ 39.9$ per acre based on the so-called expectation value, is outrageous and has nothing whatsoever to support it. On the other hand assessment on the cost value amounting to $£ 3.95$ per acre is eminently fair to both parties. If judgment is given in the amount of $£ 3.95$ per acre the claimant would not only recover his original outlay, but would also be paid a good rate of interest thereon. I submit he cannot reasonably expect more and I confidently leave the matter in your hands.

Lawyer for the Claimant: Your Worship, I am on the other hand quite confident that you will not allow yourself to be blinded to the admitted facts of the case which clearly indicate that my client has suffered far greater loss than that assessed on the basis of cost value. Let us examine the latter and use the same type of argument with which my learned friend tried to confound my witness. The assessment of $£ 3.95$ per acre is arrived at by taking the initial outlay of $£ 3.25$ per acre and adding thereto compound interest at 5 per cent. for a period of four years. Now, supposing that the plantation had been destroyed when it was five years old instead of four. If cost value were the correct basis for estimating the damage, would there be any logical reason against an assessment arrived at by adding interest for five years to the initial outlay? Of course there would be no such reason. That being so, there would be no logical reason against assessing the value of the plantation on the same basis in the sixth, seventh or eighth year. The line $C D$ which I have shown on the chart shows the rise in value of an investment of $\$ 3.25$ with 5 per cent compound interest. In the eighth year the value is £4.8. According to the arguments he used my learned friend maintains that my client could not reasonably have expected a return of more than $£ 4.8$ per acre from his plantation in the eighth year. At the same time he admits that the trees had they survived until the eighth year, could have been sold for $£ 48.5$ per acre. Such inconsistency speaks for itself. I submit that the accepted final value of $£ 48.5$ per acre is the only one on which the assessment of damage could be based and that this value discounted down to the fourth year when the plantation was destroyed actually represents the loss suffered by my client and that he should be compensated accordingly.

His Worship: The logical arguments which have been advanced for and against the cost value and expectation value methods of assessment leave one completely in the dark as to the true value of the plantation at the time it was destroyed. Since the methods give results so widely different, it is logical to assume that there must be a fallacy somewhere. Being a disinterested 
party I can perhaps point to the fallacy but it would be better if we get the opinion of a business man in the matter. I see Mr. A. in Court. We all know him to be a competent business man whose judgment can be trusted. He has been making some sort of calculations while sitting there and has listened to the arguments with some amusement showing on his face. $\mathrm{Mr}$. A., would you mind?

(Mr. A. obligingly steps into the witness box and after the usual preliminaries submits himself to question.)

Mr. A., you have listened to the arguments advanced in support of adopting the expectation value and cost value methods of assessment. Which of these two methods do you consider correct?

Mr. A.: They are both correct.

His Worship: But how, then, do you account for the widely different assessment of the value of the plantation in the fourth year?

Mr. A.: The trouble lies in the rate of interest that has been adopted in the calculations.

His Worship: But surely 5 per cent. seems fair enough, being, as explained, intermediate between the rates expected from speculative and gilt edged investments.

Mr. A.: It is a perfectly appropriate rate considered in connection with the usual run of investments, but it has no sort of connection with the case under consideration. I do not see why the parties concerned adopted it in their calculations in face of the accepted facts.

His Worship: Please explain.

Mr. A. Well, it is accepted that the claimant spent $\$ 3.25$ per acre in establishing his plantation. It is also accepted that the trees would have reached a value of $\$ 48.5$ per acre in the eighth year. Now an investment of $£ 3.25$ which increases to $£ 48.5$ per acre in eight years earns, not 5 per cent., but 40.195 per cent. compound interest. I show on the chart by means of the line $\mathrm{CB}$ the increased value, year by year, of a sum of $£ 3.25$ invested at 40.195 per cent. compound interest. You will see that in the fourth year the value is $£ 12.55$.

His Worship: Then the cost value of the plantation in the fourth year when it was destroyed was $\$ 12.55$ per acre. What about the expectation value?

Mr. A.: If you discount the anticipated final value of the plantation down for a period of four years at 40.195 per cent. compound interest, the result is also $£ 12.55$. In other words the cost and expectation values are identical, and any calculations which make them different must be fallacious somewhere.

His Worship: I see. We have heard a lot of logical arguments, but only now have been able to arrive at a logical conclusion. You maintain then, Mr. A., that $\$ 12.55$ per acre represents the maximum value that could be attached to the plantation at the time it was destroyed?

Mr. A.: Yes, provided that it at no time had or could have reached a sale value ahove the values marked by the line $\mathrm{CB}$ on the chart, or by an extension of it beyond the eighth year.

His Worship: I believe the final value of $£ 48.5$ in the eighth year is ac- 
cepted as valid by both parties. Thank you Mr. A., we now know where we stand.

(Mr. A. steps down.)

We have had presented to us two methods of arriving at the value of a plantation at the time of destruction, namely, that based on the expectation value and that based on the cost value. Both these methods seem to be sound in principle but we have seen that they lead to absurdly different results when the current rate of interest is applied in the calculations. Now I am satisfied that the expert witness, in using 5 per cent. as the rate of interest for arriving at his valuation, did so in all good faith. The use of the current rate is evidently sanctioned by his text books. One asks oneself, therefore, why the text book procedure has been accepted without being questioned in the same way as has been done to-day. The answer, it seems to me, is to be found in the fact that text book calculations are normally applied to cases where the rotation is very much longer, and the final value in relation to the initial outlay very much less than in the case we have been considering. If the rate of interest is of the same order as the current rate, there would be no great absurdity apparent in using the latter for arriving at the value of immature plantations, especially if the rotation is a long one. The longer the rotation and the younger the age at which valuation has to be made, the more likely will question be focussed on the validity of an estimate of the final value, rather than the rate of interest. If the value is sought at a time approaching the end of the rotation, the fallacy of using the current rate would also be obscured. The issue would further be clouded by the recurrent expenditure and revenue during the rotation which, presumably, must also be taken into account. In short it requires a clear cut case like the one we have been considering, one involving a very short rotation and a very high relative yield, to bring out the fallacy inherent in the use of the current rate of interest. In representing these views I am probably laying myself open to attack by experts in forest finance. Nevertheless I am sure that a plantation at any particular stage cannot have two different values. I therefore accept $\mathrm{Mr}$. A.'s interpretation of the position and judgment is accordingly given for the claimant in the sum of $\$ 251$, being the value of 20 acres destroyed at $£ 12.55$ per acre.

(The foregoing article prompted an exchange of correspondence which appeared in the ensuing issue of "The Journal, Vol. 7, Ooctober, 1941: 78.9. This exchange follows.)

Sir,

In Mr. O'Connor's article, in your last issue, on "The Value of an Imma. ture Plantation," the Magistrate, inspired by Mr. A.'s evidence, awards damages to the claimant on the basis of mean forest per cent., in this case over 40 . This does not seem equitable. All that the claimant loses is the use of his land plus the cost of establishing and tending his trees, both compounded at an assured rate of interest. The anticipated final return of $\$ 48.5$ per acre is quite problematical and, even if guaranteed by insurance against all conceivable risks, the aggregate duly compounded premiums would absorb the difference between a safe return from a low dividend paying investment and an 
anticipated return from forestry discounted back to the calamitous year at the mean forest per cent.

The claim for the present value in the fourth year might be substantiated if the claimant's investment compounded at a reasonable rate of interest, say 5 per cent., could be proved to mature at that amount. In that event the cost value in the fourth year would equal the expectation value. To satisfy this condition the land would have to be worth $£ 91.5$ per acre, and the value of the investment less the value of the land that is, the claim, £23.7. Such a claim, of course, could not be upheld without expert support of the valuation of the land, which in this instance would hardly be forthcoming.

Yours faithfully,

LIARD.

("Liard's" criticism of the Magistrate's jud'gment has been shown to Mr. O'Connor, who has kindly furnished the following reply. Editor.)

Liard says (a) the claimant lost only the use of his land plus the cost of establishment, both compounded at an assured rate ( 5 per cent?) of interest and (b) the anticipated final return was quite problematical. As regards (a), the defendant held a similar view, which he was unable to maintain against the arguments advanced by the claimant. As regards (b), the final return was not in dispute at all. Reading his two statements together one concludes that Liard denies the validity of any assessment based on expectation value.

He says further that even if the final return could be guaranteed by insurance, the aggregate premiums would absorb the difference between a "safe return from a low dividend paying investment and an anticipated return from forestry at the mean forest per cent." Well, now, let us call 5 per cent, a safe return and, to guarantee the final return, let us insure and add to the original initial cost $(£ 3.25$ per acre) the initial value of all insurance premiums such that the mean forest per cent. becomes 5 per cent. The initial investment will then be $\$ 32.83$ per acre, the value of which increases at 5 per cent. to $\$ 48.5$ per acre in the eighth year. In the fourth year the value is $£ 39.9$ per acre. Liard, while he maintains that the judgment granting the claimant compensation at the rate of $\$ 12.55$ per acre (representing over 40 per cent interest) was unjust to the defendant, nevertheless implies that compensation at $£ 39.9$ per acre would have been quite fair because the rate of interest in this case would have been no more than 5 per cent.

I am afraid I do not see the relevancy of the remark that the investment would have earned 5 per cent. compound interest if the value of the land was $\$ 91.5$ per acre. The value of the land is its market value. How does the land enter into the calculation anyway unless the growing of the trees or their destruction altered its market value?

(Editor's Note: The foregoing article has been reproduced in consideration of the interest in the question of the value to be assigned to young growth in the compilation of forest fire statistics. The author has taken the stand that all that is necessary is to assume an average rotation and an average yield and value in order to solve the problem. The forest per cent is determined by these data and is not, therefore, a matter for discussion.) 